\title{
РЕЗУЛЬТАТИ ВИКОРИСТАННЯ ІНТЕГРОВАНОЇ ПРОГРАМИ ФІЗИЧНОЇ РЕАБІЛІТАЦІЇ СПОРТСМЕНІВ ПІСЛЯ УШКОДЖЕНЬ ГОМІЛКОВО-СТУПНЕВОГО СУГЛОБА
}

\author{
Юсеф Шарбель ${ }^{1}$ \\ ${ }^{1}$ Харківська державна академія фізичної культури, Харків, Україна, frir@ukr.net \\ https://doi.org/10.29038/2220-7481-2019-01-91-97
}

\begin{abstract}
Анотаціï
Mema роботи - покращення результатів фізичної реабілітації спортсменів-футболістів із внутрішньосуглобовими пошкодженнями гомілково-ступневого суглоба на амбулаторному етапі за допомогою оптимізації та підвищення ефективності комплексного застосування реабілітаційних заходів, які інтегровано в тренувальний процес. Результати роботи. В основу роботи покладено результати спостереження за 36 спортсменами 18 24 років, котрі займаються футболом й отримали внутрішньосуглобові пошкодження гомілково-ступневого суглоба та перебувають на амбулаторному етапі лікування. Дослідження проводили в клініці Медичного центру «MirMajidErslan» м. Бейрут (Ліван) на базі кабінету фізичної терапії. Травмовані спортсмени контрольної групи отримали комплекс реабілітаційних заходів за традиційною програмою фізичної реабілітації, прийнятою в цій клініці. Постраждалим основної групи запропоновано комплекс реабілітаційних заходів згідно 3 розробленою нами програмою, що включав використання інтегрованої в тренувальний процес лікувальної гімнастики й процедур модифікованої етнічної арабської лазні та послідовне застосування процедур з елементами етнічного арабського масажу. Методи дослідження. Для оцінки ефективності заходів фізичної реабілітації травмованих спортсменів використано 100-бальную шкалу оцінки результатів лікування NEER (Neer-Grantham-Shelton (1967) у модифікації D. Cherkes-Zade, M. Monesi, A. Causero, M. Marcolini (2003)). Для вивчення динаміки зміни якості життя травмованих спортсменів та рівня професійної реабілітації застосовано медико-соціологічні методики, а саме: візуальну аналогову шкалу (VisualAnalogScale, VAS) й анкету EuroQol-5D. Висновки. Аналіз результатів проведеної фізичної реабілітації засвідчив, що за позитивної динаміки змін функціонального стану постраждалих обох клінічних груп більш виражені та достовірно кращі результати отримано в постраждалих основної групи, яким проведено фізичну реабілітацію згідно із запропонованою нами програмою.
\end{abstract}

Ключові слова: гомілково-ступневий суглоб, фізична реабілітація, східний масаж, східна лазня, амбулаторний етап.

Юсеф Шарбель. Результаты использования интегрированной программы физической реабилитации спортсменов после повреждений голеностопного сустава. Цель работы - улучшение результатов физической реабилитации спортсменов-футболистов с внутрисуставными повреждениями голеностопного сустава на амбулаторном этапе путем оптимизации и повышения эффективности комплексного применения реабилитационных мероприятий, которые интегрированы в тренировочный процесс. Результаты работы. Основой данной работы были результаты наблюдения за 36 спортсменами, занимающимися футболом в клинике Медицинского центра «MirMajidErslan» г. Бейрут (Ливан) на базе кабинета физической терапии. Пострадавшие контрольной группы получили комплекс реабилитационных мероприятий по традиционной программе физической реабилитации, принятой в данной клинике. Meтоды исследования. Пострадавшим основной группы предложен комплекс реабилитационных мероприятий разработанной нами программы, который включал использование интегрированной в тренировочный процесс лечебной гимнастики, а также процедур модифицированной этнической арабской бани и этнического арабского массажа. Bыводы. При позитивной динамике изменений функционального состояния пострадавших обеих клинических групп более выраженные и достоверно лучшие результаты получены у пострадавших основной группы, которым проводилась физическая реабилитация по предложенной нами программе.

Ключевые слова: голеностопный сустав, физическая реабилитация, восточный массаж, восточная баня, амбулаторный этап.

Sharbel Youssef. Results of the use of Integratedprogram of Physical Rehabilitation of Sportsmen after Damages of Ankle Joint. The aim of work was an improvement of results of physical rehabilitation of sportsmen of playing types of sport (on the example of football) with the intra-articular damages of ankle joint on the ambulatory stage by optimization and increase of efficiency of the differentiated application of rehabilitation measures, computer-integrated in a training process. In basis of this work was the fixed results of watching 36 sportsmen of 18-24, which engage in football, which got the inwardly-arthral damages of ankle joint, and are on the ambulatory stage of treatment. Researches 
were conducted in the clinic of the Medical center of «Mir Majid Erslan» of Beirut (Lebanon) on the base of cabinet of physical therapy. The trauma sportsmen of control group got the complex of rehabilitation measures on the traditional program of physical rehabilitation, accepted in this clinic. Injured basic group there was the offered complex of rehabilitation measures according to worked out by us programs, which included for itself the use of integrated in a training process medical gymnastics by the use of procedures of the modified ethnic Arabic bath-house by the successive use of procedures with the elements of the ethnic Arabic massage. For the estimation of efficiency of measures of physical rehabilitation of sportsmen we used the 100-levels scale of estimation of results of treatment of NEER (Neer - Grantham Shelton (1967) in modification of D. Cherkes-Zade, M. Monesi, A. Causero, M. Marcolini (2003)). For the study of dynamics of change of quality of life of sportsmen and level of professional rehabilitation we used medic and sociological methodologies, namely: visual analog scale (Visual Analog Scale, VAS) and questionnaire of EuroQol-5D. The analysis of results of the conducted physical rehabilitation showed that at the positive dynamics of changes of the functional state of injured both clinical groups more expressed and for certain the best results were got in a victim basic group, which conducted a physical rehabilitation in obedience to the program offered byus.

Key words: ankle joint, physical rehabilitation, east massage, east bath-house, ambulatory stage.

Вступ. Травми гомілково-ступневого суглоба становлять до $15 \%$ серед усіх суглобових ушкоджень, при цьому основний контингент людей із цією патологією - особи працездатного віку, а саме спортсмени $[4 ; 14]$.

Гомілково-ступневий суглоб є складним суглобом, на який покладено значне навантаження, особливо в спорті, а тому він часто схильний до травматичних ушкоджень. Складність анатомічної будови та слабка захищеність м'якими тканинами при систематичних високих навантаженнях і частих травматичних діях призводять до того, що механічна міцність його елементів виявляється недостатньою $[3 ; 5 ; 12]$.

Вивихи й переломи сягають 30-50 \% серед усіх травм гомілково-ступневого суглоба і до $12 \%$ серед усієї патології опорно-рухової системи. Пошкодження зв’язково-капсульного апарату гомілковоступневого суглоба за поширеністю займають друге місце після патології менісків та становлять до $15 \%$ серед усіх травм суглобів. Внутрішньосуглобові переломи гомілково-ступневого суглоба сягають 1,5-4,0 \% серед усіх переломів кісток скелета й 5-7 \% усіх внутрішньосуглобових переломів. Більшості постраждалих із такими пошкодженнями потрібне тривале лікування [7; 9; 11$]$.

Великий відсоток отримання інвалідності при відкритих ушкодженнях гомілково-ступневого суглоба становить 9,3-17,4 \%, що свідчить про наявність невирішених питань під час лікування таких ушкоджень [12].

На сьогодні доцільні подальше вдосконалення, пошук і впровадження в процес реабілітації після внутрішньосуглобових ушкоджень гомілково-ступневого суглоба найбільш прогресивних та науково обгрунтованих технологій. Їх використання має бути комплексним та передбачати диференційований підхід до вибору форм і засобів залежно від характеру ушкоджень як кістково-хрящових структур суглоба, так і м'яких тканин, що його оточують [2; 8; 12].

Необхідність повернення кваліфікованих спортсменів до активної тренувальної й змагальної діяльності встановлює високі вимоги не лише до їх медичного забезпечення, а й до подальшого відновлення їхнього здоров'я. При цьому потрібно враховувати можливі матеріальні витрати та мати на меті їх скорочення, у тому числі за рахунок удосконалення комплексу реабілітаційних заходів на всіх етапах, а особливо на амбулаторному [10].

Головна мета фізичної реабілітації як складової частини медичного реабілітаційного процесу комплексний процес відновлення здоров'я, фізичного стану й працездатності постраждалих із застосуванням із лікувальною й профілактичною метою фізичних вправ та природних чинників [1; 13].

Мета дослідження - обгрунтувати структуру й зміст програми фізичної реабілітації спортсменів ігрових видів спорту (на прикладі футболу) із внутрішньосуглобовими пошкодженнями гомілковоступневого суглоба на амбулаторному етапі.

Методи дослідження. Під час проведення комплексних медичних обстежень за участі спортсменів дотримувалися Гельсинської декларації Всесвітньої медичної асоціації щодо етичних принципів медичних досліджень за участю людини в ролі об'єкта дослідження. Зміст максимальних тестових навантажень i процедур вимірів фізіологічних показників відповідали Міжнародним правилам та вимогам для біомедичних досліджень за участі людей. Особи, котрих тестували, були ознайомлені зі змістом тестів, процедур вимірів і давали згоду на їх проведення.

У педагогічному експерименті, представленому в цьому дослідженні, брали участь 36 постраждалих спортсменів - футболістів чоловічої статі, які отримали внутрішньосуглобові пошкодження гомілково-ступневого суглоба. 
Травмовані спортсмени, які взяли участь у дослідженні, мали вік 18-24 років. Середній вік становив $(22,8 \pm 1,3)$ років в основній групі та $(21,7 \pm 2,1)$ - уконтрольній.

Дослідження проводили в клініці Медичного центру «MirMajidErslan» м. Бейрут (держава Ліван) на базі кабінету фізичної реабілітації. Більшість постраждалих - мешканці м. Бейрут. У дослідженні взяли участь травмовані спортсмени із закритими ушкодженнями гомілково-ступневого суглоба типів A1, A2, C1 і С2 за класифікацією AO/ASIF [4].

Усіх травмованих спортсменів поділено на дві рівноцінні клінічні групи - основну й групу контролю (по 18 у кожній). Давність травми - від п'яти тижнів до двох місяців. При цьому травмовані спортсмени обох клінічних груп проходили курс реабілітаційного лікування вперше.

Усі травмовані спортсмени обох груп безпосередньо перед реабілітаційним лікуванням і по його завершенню проходили первинне й повторне обстеження - за 30 днів після його початку, що давало змогу оцінити динаміку змін показників систем організму.

Для оцінки ефективності заходів фізичної реабілітації травмованих спортсменів використано 100-бальную шкалу оцінки результатів лікування NEER (Neer-Grantham-Shelton у модифікації

D. Cherkes-Zade) [6;12].

Для вивчення динаміки зміни якості життя травмованих спортсменів та рівня професійної реабілітації застосовано медико-соціологічні методики, а саме: візуальну аналогову шкалу VAS (VisualAnalogScale) та анкету EuroQol-5D [8].

Цифровий матеріал, отриманий у процесі дослідження, оброблено за допомогою пакета програм обробки даних загального призначення Statisticafor Windows версії 6.0. Достовірність різниць між групами (порівняння середніх значень показника за кожною групою) визначали за допомогою критерію Стьюдента (t). Рівень вірогідності прийнято за $95 \%$.

Результати дослідження. Травмовані спортсмени I (контрольної) групи отримали комплекс реабілітаційних заходів за традиційною програмою фізичної реабілітації, прийнятою в клініці Медичного центру «MirMajidErslan» м. Бейрут. Постраждалим спортсменам I групи на тиждень призначено три сеанси магнітотерапії з індукцією магнітного поля до 30 мТ. Лазеротерапію в цій фазі у всіх пацієнтів використовували тричі 3 урахуванням виду монохромності випромінювання на гомілково-ступневий суглоб та рефлексогенні зони, але, зазвичай, у постійному режимі з потужністю до 25 мВт по 15-30 секунд кожна. Загальний час процедури становив 3 хв. Магнітотерапію призначали всім постраждалим спортсменам I групи - три сеанси (із попередніми характеристиками), лазеротерапію - три сеанси з тотожною потужністю.

Постраждалим II групи комплекс реабілітаційних заходів призначали лікування згідно із запропонованою нами програмою комплексного застосування засобів фізичної реабілітації травмованих спортсменів, яка включала використання лікувальної гімнастики й була інтегрована в тренувальний процес, а також масаж 3 елементами етнічного арабського масажу 3 використанням процедур модифікованої етнічної арабської лазні.

Нами розроблено комплекс заходів фізичної реабілітації, який складався 3 поєднаного застосування лазневої процедури традиційної арабської лазні та процедури масажу в комбінації з масажними прийомами східного масажу й був інтегрований у тренувальний процес. У нашому дослідженні, обираючи східну лазню як засіб фізіотерапії для постраждалих спортсменів із наслідками внутрішньосуглобових пошкоджень гомілково-ступневого суглоба, ми керувалися такими причинами:

1. Традиційною популярністю відвідин східної лазні в Лівані та ії̈ застосуванням як профілактичного й терапевтичного засобу.

2. Автентичністю вживаної лазні та історичним етнічним і культурним традиціям населення Лівану.

3. Травмовані спортсмени, які брали участь у дослідженні, мали побутовий досвід використання східної лазні та володіли основами методики паріння.

Нами доповнено методику па риння в східній лазні, яка мала деякі відмінності від традиційної, зокрема:

1. Обмеження часу процедури $100-120$ хвилинами;

2. Кількість процедур на тиждень - три (понеділок, середа та п'ятниця);

3. Контроль стану пацієнта й ступеня дії кожної процедури, який виражався в моніторингу лікарем артеріального тиску та частоти серцевих скорочень до й після процедури, а також самоаналізу пацієнтом свого фізичного стану; 
4. Застосування в кінці процедури теплого душу та повітряного охолодження;

5. Відсутність традиційного пілінгу рукавицею Кесе й мильного масажу. Модифіковану нами процедуру східного масажу проводили з акцентом на травмовану кінцівку.

6. Контроль стану травмованих спортсменів здійснювали за опитуванням погіршення самопочуття при появі дискомфортних суб'єктивних відчуттів, за зовнішніми ознаками змін стану, за вимірюванням АТ і ЧСС у процесі процедури.

Для кожної частини програми східного масажу та етнічної лазневої процедури визначено мету й завдання фізичної реабілітації, а також методичну послідовність їх виконання.

При цьому враховували особливості періоду реабілітації, а також кількісні та якісні клінічні показники (анкетування, соматоскопія, антропометрія, гоніометрія, пульсометрія, артеріальна тонометрія тощо).

Процедури розробленої нами для спортсменів-футболістів із внутрішньосуглобовими пошкодженнями гомілково-ступневого суглоба програми комплексного застосування засобів фізичної реабілітації, інтегрованої в тренувальний процес, призначали диференційовано в кожному окремому випадку й застосовували індивідуально.

Тобто розроблена програма комплексного застосування засобів фізичної реабілітації грунтується на кількісних показниках функціональних можливостей опорно-рухового апарату травмованого спортсмена в цілому, коректному підборі режимів відновлення 3 урахуванням індивідуальних особливостей, ступеня клінічних та функціональних порушень.

Результати використання традиційної програми фізичної реабілітації під час оцінки за методикою NEER y I (контрольній) групі після лікування дещо покращилися, а саме - кількість незадовільних результатів зменшилася на $5,6 \%$, частка задовільних результатів - на $22,2 \%$, за рахунок двократного збільшення частки добрих результатів до 55,6 \% (табл. 1).

\section{Результати фізичної реабілітації постраждалих спортсменів I (контрольної) групи за методикою NEER}

\begin{tabular}{|c|c|c|c|c|}
\hline \multirow{3}{*}{ Результат лікування } & \multicolumn{4}{|c|}{ Термін спостереження } \\
\hline & \multicolumn{2}{|c|}{ до лікування } & \multicolumn{2}{|c|}{ після лікування } \\
\hline & абс. & $\%$ & абс. & $\%$ \\
\hline Добрі & 5 & 27,8 & 10 & 55,6 \\
\hline Задовільні & 9 & 50 & 5 & 27,8 \\
\hline Незадовільні & 4 & 22,2 & 3 & 16,6 \\
\hline Усього & 18 & 100 & 18 & 100 \\
\hline
\end{tabular}

Після курсу комплексного застосування засобів фізичної реабілітації за запропонованою нами програмою результати в II (основній) групі значно покращилися, а саме: кількість добрих результатів збільшилася на $50 \%$ за рахунок значного зменшення задовільних - на 27,8 \% та відсутності незадовільних результатів після проведеного реабілітаційного лікування (табл. 2).

Таблиия 2

\section{Результати фізичної реабілітації постраждалих спортсменів II (основної) групи за методикою NEER}

\begin{tabular}{|l|c|c|c|c|}
\hline \multirow{2}{*}{ Результат лікування } & \multicolumn{4}{|c|}{ Термін спостереження } \\
\cline { 2 - 5 } & \multicolumn{2}{|c|}{ до лікування } & пбс. & після лікування \\
\cline { 2 - 5 } & aб́c. & \% & 13 & 72,2 \\
\hline Добрі & 4 & 22,2 & 5 & 27,8 \\
\hline Задовільні & 10 & 55,6 & - & - \\
\hline Незадовільні & 4 & 22,2 & 18 & 100 \\
\hline Усього & 18 & 100 & \\
\hline
\end{tabular}

Згідно з анкетою EuroQol-5D на початку реабілітаційних заходів за традиційною програмою в I (контрольній) групі кількість добрих результатів несуттєво збільшилася - на 5,6 \%, очевидно, що за рахунок такого ж зменшення чисельності незадовільних результатів, оскільки кількість задовільних залишилася незмінною - 33,3 \% (табл. 3). 
Результати фізичної реабілітації постраждалих спортсменів I (контрольної) групи за анкетою EuroQol-5D

\begin{tabular}{|l|c|c|c|c|}
\hline \multirow{2}{*}{ Результат лікування } & \multicolumn{4}{|c|}{ Термін спостереження } \\
\cline { 2 - 5 } & \multicolumn{2}{|c|}{ до лікування } & \multicolumn{2}{c|}{ після лікування } \\
\cline { 2 - 5 } & абс. & \% & aбc. & \% \\
\hline Добрі & 9 & 50 & 10 & 35,6 \\
\hline Задовільні & 6 & 33,3 & 6 & 11,1 \\
\hline Незадовільні & 3 & 16,7 & 2 & 100 \\
\hline Усього & 18 & 100 & 18 & \\
\hline
\end{tabular}

Використання програми комплексного застосування засобів фізичної реабілітації за запропонованою нами програмою дало змогу більш суттєво за контрольну групу покращити результати, а саме: кількість добрих результатів збільшилася удвічі - до 88,9 \%, задовільних - зменшилася в 3,5 раза й становила $11,1 \%$, а незадовільних результатів не простежено (табл. 4).

\section{Результати фізичної реабілітації постраждалих спортсменів II (основної) групи за анкетою EuroQol-5D}

\begin{tabular}{|l|c|c|c|c|}
\hline \multirow{2}{*}{ Результат лікування } & \multicolumn{4}{|c|}{ Термін спостереження } \\
\cline { 2 - 5 } & \multicolumn{2}{|c|}{ до лікування } & \multicolumn{2}{c|}{ після лікування } \\
\cline { 2 - 5 } & абс. & \% & абс. & \% \\
\hline Добрі & 8 & 44,4 & 16 & 11,1 \\
\hline Задовільні & 7 & 38,9 & 2 & - \\
\hline Незадовільні & 3 & 16,7 & - & 100 \\
\hline Усього & 18 & 100 & 18 & \\
\hline
\end{tabular}

Показник ВАШ у I (контрольній) групі за 1 тиждень після початку реабілітації покращився та становив $6,2 \pm 0,41$, у терміни 2 - і 3 -го тижнів спостерігали його подальше покращення $(5,3 \pm 0,37$ та 4,4 $\pm 0,28$ відповідно), а максимальне суб’єктивне поліпшення наступало в термін 4 тижні $(2,9 \pm 0,22)$, тобто в кінці лікування $(\mathrm{p}<0,05)$.

У постраждалих II (основної) групи значення ВАШ покращуються, починаючи 31 тижня реабілітації $(5,7 \pm 0,38)$. При цьому зберігається чітке зниження больових відчуттів у терміни діва та три тижні,

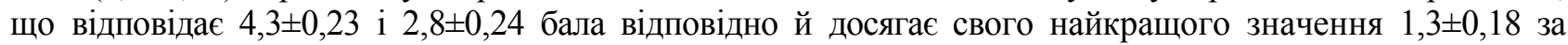
чотири тижні від початку реабілітації ( $<<0,05)$, (табл.5).

Таблиия 5

Показники ВАШ обох клінічних груп залежно від термінів спостереження

\begin{tabular}{|l|c|c|}
\hline \multirow{2}{*}{ Термін спостереження } & \multicolumn{2}{|c|}{ Значення ВАШ } \\
\cline { 2 - 3 } & І (контрольна) група & II (основна) група \\
\hline Початковий рівень & $8,4 \pm 0,36$ & $8,4 \pm 0,21$ \\
\hline 1-й тиждень & $6,2 \pm 0,41$ & $5,7 \pm 0,38$ \\
\hline 2-й тиждень & $5,3 \pm 0,37$ & $4,3 \pm 0,23$ \\
\hline 3-й тиждень & $4,4 \pm 0,28$ & $2,8 \pm 0,24$ \\
\hline 4-й тиждень & $2,9 \pm 0,22$ & $1,3 \pm 0,18$ \\
\hline * $<0,05$ & \multicolumn{2}{|c}{} \\
\hline
\end{tabular}

Послідовність виконання заходів реабілітаційного процесу передбачає підбір адекватних методів обстеження травмованих спортсменів для виявлення наявних обмежень їхніх функціональних можливостей. Визначено завдання та підібрано засоби фізичної реабілітації.

Запропонована програма реабілітаціїзабезпечує індивідуальний підхід до призначення засобів відновного лікування, який залежить від ступеня функціональних порушень і загального стану постраждалого. Крім того, вона дає змогу проводити оцінку та своєчасну необхідну оперативну корекцію реабілітаційних заходів.

Розроблена програма фізичної реабілітації також сприяє впливу на певні ланки патологічного процесу травмованого суглоба. Оптимізація м'язового тонусу ураженої кінцівки, покращення процесів 
iï макро- та мікроциркуляції, загальна стимуляція регенераторних процесів поліпшують відновлення функціональної здатності гомілково-ступневого суглоба, покращують якість життя постраждалих спортсменів і прискорюють їх повернення до повноцінної спортивної діяльності.

У травмованих спортсменів чітко простежується покращення клінічних та функціональних показників ефективності проведеного реабілітаційного лікування, що свідчить про наявність ефекту й виражену позитивну динаміку після проведеної програми комплексного застосування запропонованим поєднанням засобів фізичної реабілітації. Це є підставою рекомендувати іiї до використання в практичній роботі лікувально-профілактичних і спортивно-фізкультурних закладів відповідного профілю.

Перспективи подальшого дослідження полягають у розробці програм фізичної реабілітації, які можуть бути інтегровані в тренувальний процес із застосуванням етнічних фізіологічних засобів впливу на ушкоджений сегмент й організм загалом.

Висновки та перспективи подальших досліджень. Аналітична обробка отриманих результатів дослідження свідчить про позитивну динаміку змін функціонального стану постраждалих обох клінічних груп, але більш виражені й достовірно кращі результати отримано саме в постраждалих II (основної) групи, яким проведено фізичну реабілітацію згідно із запропонованою нами програмою 3 використанням інтегрованої в тренувальний процес лікувальної гімнастики, процедур модифікованої етнічної арабської лазні й послідовним використанням процедур з елементами етнічного арабського масажу.

Застосування методик оцінки ефективності заходів фізичної реабілітації травмованих спортсменів NEER (Neer-Grantham-Shelton), візуальної аналогової шкали VAS та анкети EuroQol-5D задля вивчення динаміки зміни якості життя спортсменів і рівня професійної реабілітації дало змогу об'єктивно визначити зменшення кількості незадовільних та задовільних результатів і збільшення добрих результатів у контрольній групі, а в спортсменів основної групи дало змогу визначити достовірно більше добрих та задовільних результатів за відсутності незадовільних, що доводить перевагу запропонованої програми фізичної реабілітації.

У постраждалих спортсменів II (основної) групи виявлено достовірно кращі за контрольну групу показники застосованих методик і шкал оцінки результатів в однакові терміни спостереження, що свідчить про наявність отриманого ефекту й про виражену позитивну динаміку в стані постраждалих спортсменів після проведеної програми комплексного застосування засобів фізичної реабілітації.

Запропонована програма фізичної реабілітації травмованих спортсменів після внутрішньосуглобових ушкоджень гомілково-ступневого суглоба на амбулаторному етапі, що інтегрована в тренувальний процес, $є$ ефективною та може бути рекомендована до загального професійного використання.

\section{Джерела та література}

1. Бабовников В. Г., Бабовников А. В., Цыпурский И. Б. Лечение переломов дистального метаэпифиза большеберцовой кости. Вестник травматологии и ортопедии им. Н. Н. Приорова. 2003. 1. С. $42-45$.

2. Битчук Д. Д., Истомин А. Г., Каминский, А. В., Торяник И. И. Лечение открытых повреждений голеностопного сустава с использованием низко интенсивного лазерного излучения. Вісник морської медицини. 2006. 3 (34). С. $15-20$.

3. Бондаренко А. В., Располова Е. А., Пелеганчук В. А. Факторы, оказывающие влияние на заживление кожной раны при лечении открытых диафизарных переломов костей голени. Анналы травматологии и ортопедии. 2001. 1. С. 76-79.

4. Борзих О. В. Класифікація ускладнень ушкоджень кінцівок. Травма. 2003.4 (5). С. 594-598.

5. Бялик Е. И., Соколов В. А., Семенова М. Н., Евдокимова Н. В. Особенности лечения открытых переломов длинных костей у пострадавших с политравмой. Вестник травматологии и ортопедии им. Н. H. Приорова. 2002. 4. С. 3-8.

6. Гайко Г. В., Калашніков А. В., Вдовіченко К. В. Вибір методу лікування хворих із діафізарними переломами великогомілкової кістки. Украӥнський медичний альманах. 2010. 13 (1). С. $40-43$.

7. Коваленко В. Н., Борткевич О. П. Остеоартроз: практическое руководство. Киев: Морион, 2003. C. $365-369$.

8. Коструб А. А., Грицай Н. П., Вернигора И. П. Лечение гнойных осложнений при травмах крупных суставов нижних конечностей. Ортопедия, травматология и протезирование. 1995. № 1. С. 48-50.

9. Ломтатидзе Е. Ш., Ломтатидзе В. Е., Поцелуйко С. В. Функциональные результаты консервативного и оперативного лечения переломов лодыжек. Лечение сочетанных травм и заболеваний конечностей: сб. материалов всерос. науч.-практ. конф. Москва, 2003. С. 204-205.

10. Сокрут В. Н., Яблучанский Н. И. Медицинская реабилитация: учебник. Славянск: Ваш имидж, 2015. C. 245-247. 
11. Миренков К. В., Гацак В. С., Мелашенко С. А. Восстановительные операции при сложных переломах голеностопного сустава. 2004. Травма. 5 (3). С. 322-327.

12. Никитченко И. И., Поляков Д. А. Анализ лечения больных с последствиями внутри- и околосуставных переломов нижних конечностей. Человек и его здоровье: материалы десятого юбилейного Рос. нац. конгресса. Санкт-Петербург, 2005. С. 211-212.

13. Побел А. Н., Пелещук И. Л., Амро Т. А. Оперативное лечение около- и внутрисуставных переломов дистального отдела костей голени. Ортопедия, травматология и протезирование. 2003. 3. С. 59-62.

14. Травматологія та ортопедія: нормативне вироб.-практ. вид. Київ: МНІАЦ мед. стат.; МВЦ «Медінформ», 2009. С. 168-171.

15. Черныш В. Ю. Структура осложнений и патогенетические аспекты их предупреждения при различных методах лечения внутрисуставных переломов костей, образующих коленный и голеностопный сустав. травма. 2001.2 (2). С. 155-159.

\section{References}

1. Babovnikov, V. G., Babovnikov, A. V., Tsyipurskiy, I. B. (2003). Lechenie perelomov distalnogo metaepifiza bolshebertsovoy kosti [Treatment of tibial distal metaepiphysis of shinbone]. Vestnik travmatologii $i$ ortopedii im. N. N. Priorova, no 1, 42-45.

2. Bitchuk, D. D, Istomin, A. G., Kaminskiy, A. V., Toryanik, I. I. (2006). Lechenie otkrytyh povrezhdeniy golenostopnogo sustava s ispolzovaniem nizkointensivnogo lazernogo izlucheniya [Treatment of open injuries of the ankle joint using low-intensity laser radiation].Visnyk morskoyi meditsyny, no. 3 (34), 15-20.

3. Bondarenko, A. V., Raspolova, E. A., Peleganchuk, V. A. (2001). Faktory, okazyvayuschie vliyanie na zazhivlenie kozhnoy rany pri lechenii otkryitih diafizarnyh perelomov kostey goleni [Factors affecting the healing of skin wounds in the treatment of open diaphyseal fractures of the lower leg bones]. Annaly travmatologii $i$ ortopedii, no. 1, 76-79.

4. Borzykh, O. V. (2003). Klasyfikatsiia uskladnen ushkodzhen kintsivok [Classification of limb injuries complications]. Travma, no. 4 (5), 594-598.

5. Byalik, E. I., Sokolov, V. A., Semenova, M. N., Evdokimova, N. V. (2002). Osobennosti lecheniya otkryityih perelomov dlinnyih kostey u postradavshih s politravmoy [Features of treatment of open fractures of long bones in victims with polytrauma]. Vestnik travmatologii i ortopediiim. N. N. Priorova, no. 4, 3-8.

6. Haiko, H. V., Kalashnikov, A. V., Vdovichenko, K. V. (2010). Vybir metodu likuvannia khvorykh iz diafizarnymy perelomamy velykohomilkovoi kistky [The choice of the method of treatment of patients with diaphyseal fractures of the tibia]. Ukrainskyi medychnyi almanakh, no.13 (1), 40-43.

7. Kovalenko, V. N., Bortkevich, O. P. (2003). Osteoartroz: prakticheskoe rukovodstvo [Osteoarthritis: a practical guide]. Kiev: Morion, 365-369.

8. Kostrub, A. A., Gritsay, N. P., Vernigora, I. P. (1995). Lechenie gnoynyh oslozhneniy pri travmah krupnnyh sustavov nizhnih konechnostey [Treatment of purulent complications in injuries of large joints of the inferior limbs]. Ortopediya, travmatologiya i protezirovanie, no.1, 48-50.

9. Lomtatidze, E. Sh., Lomtatidze, V. E., Potseluyko, S. V. (2003). Funktsionalnyie rezultaty konservativnogo i operativnogo lecheniya perelomov lodyihek [Functional results of conservative and surgical treatment of ankle fractures]. Lechenie sochetannyih travm $i$ zabolevaniy konechnostey: sbornik materialov vserossiyskoy nauchno-prakticheskoy konferentsii. Moskva, 204-205.

10. Sokrut, V. N., Yabluchanskiy, N. I. (2015). Meditsinskaya reabilitatsiya [Medical rehabilitation]: uchebnik. Slavyansk: Vash imidzh, 245-247.

11. Mirenkov, K. V., Gatsak, V. S., Melashenko, S. A. (2004). Vosstanovitelnyie operatsii pri slozhnyh perelomah golenostopnogo sustava [Reconstructive surgery for complex ankle fractures]. Travma, no. 5 (3), $322-327$.

12. Nikitchenko, I. I., Polyakov, D. A. (2005). Analiz lecheniya bolnyh s posledstviyami vnutri- iokolosustavnyh perelomov nizhnih konechnostey [Analysis of the treatment of patients with the consequences of intra-and periarticular fractures of the inferior limbs]. Chelovek $i$ ego zdorove: materialyi desyatogo yubileynogo Rossiyskogo natsionalnogo kongressa. Sankt-Peterburg, 211-212.

13. Pobel, A. N., Peleschuk, I. L., Amro, T. A. (2003). Operativnoe lechenie okolo- i vnutrisustavnyh perelomov distalnogo otdela kostey goleni [Surgical treatment of near-and intra-articular fractures of the distal part of the leg bones]. Ortopediya, travmatologiya i protezirovanie, no. 3, 59-62.

14. Travmatolohiia ta ortopediia: Normatyvne vyrobnycho-praktychne vydannia [Traumatology and orthopedics: Normative production and practical edition.]. (2009). Kyiv: MNIATs medychnoi statystyky; MVTs «Medinform», 168-171.

15. Chernysh, V. Yu. (2001). Struktura oslozhneniy i patogeneticheskie aspektyi ih preduprezhdeniya pri razlichnyh metodah lecheniya vnutrisustavnyh perelomov kostiey, obrazuyuschih kolennyiy i golenostopnyiy sustav [The structure of complications and the pathogenetic aspects of their prevention in various methods of treatment of intraarticular bone fractures that form the knee and ankle joint]. Travma, no. 2 (2), 155-159.

Стаття надійшла до редакції 21.03.2019 р. 